\title{
Por uma política que deixe a escola agir livremente
}

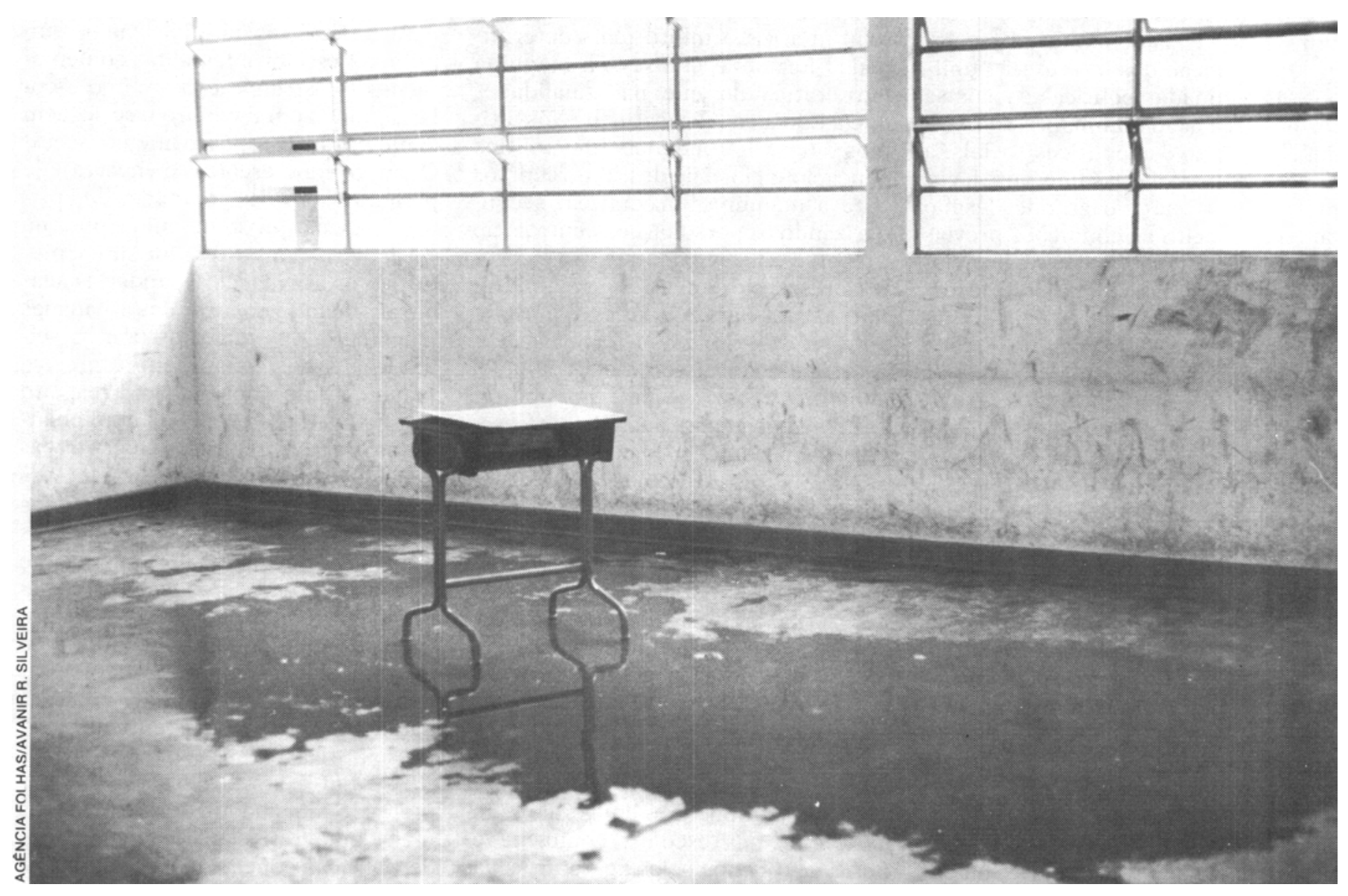

Moacir Gadotti é professor universitário, pedagogo e, atualmente, é assessor de Paulo Freire na Secretaria Municipal de Educaçào de Sào Paulo. Seu depoimento a seguir baseia se numa intervençào que fez, recentemente, num debate sobre um projeto de Educaçáo para o

Brasil, de acordo com as diretrizes do Partido dos Trabalhadores (PT).

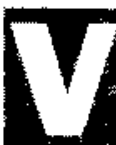
ive-se falando em crise na educaçào sem verificar o quanto se caminhou.

Em contrapartida ao otimismo, queria opor um certo pes. simismo, para realizar justamente uma dialeticidade na leitura da reali. dade. De inicio quero tratar da Constituiçảo e das normas constitucionais que foram apresentadas como avançadas e possíveis de se constituirem em referência para a construçáo de um programa a ser realizado. Eu gostaria de apontar alguns problemas nestas normas constitucionais, que demonstram, no meu entender, o quanto nossas conquistas foram limitadas. O eumprimento destas normas constitucionais é muito problemático. Neste ano, por exemplo, o próprio Ministro da Educaçào declarou que nào há condiçỏes para cumprir o Artígo 60 das "disposiçōes transitórias" que prevê que, no mínimo, $50 \%$ do orçamento do MEC seja aplicado no ensino fundamental e na erradicaçào do analfabetismo. Ele se declarou sem qualquer condiçáo de fazê-lo, pois teria que prejudicar as Universidades, já que $80 \%$ do orçamento, segundo o Ministro, é aplicado no ensino superior. Há, portanto, um des- 
cumprimento desse artigo que prevê em dez anos a eliminaçào do analfabetismo e a universalizaçào do ensino fundamental. Então, são normas constitucionais que nào sào respeitadas. Portanto, nesse aspecto, temos até boas leis, mas nào hả condiçòes de aplicabilidade. Normas nāo faltam, o que faltam sāo programas, planos de açāo prática que possam interferir significativamente nessa realidade. Nosso Pais tem hoje aproximadamente 35 milhóes de analfabetos e 8,5 milhòes de crianças em idade escolar fora da Escola.

Apesar dessas conquistas, os indices de evasào da primeira para a segunda série continuam os mesmos, nos últimos einqüenta anos. Fala-se muito em expansāo quantitativa da Escola. Afirma-se que a Lei $n^{\circ}$ $5692 / 71$ representou, no que diz respeito à organizaçāo da Escola, um avanço considerável, mas,na verda. de, ela nào conseguiu transformar a realidade neste aspecto. Os dados mostram que $o$ indice de analfabetismo nacional continua praticamente $o$ mesmo e a última estatística publicada em março, pelo IBGE, fruto da Pesquisa Nacional por Amostra de Domicilios, aponta uma mudança no indice de analfabetismo. Nos últimos cem anos, é a primeira vez que há acréscimo da porcentagem de analfabetismo: de $25,59 \%$ para $25,76 \%$. Houve, portanto, um aumento consideravel do contingente de analfabetos no Brasil. Esse é um dado alarmante. As condiçōes da perversidade estào se aprofundando.

Além disso, tivemos derrotas consideráveis na Constituinte, por exemplo, as verbas publicas para as Escolas confessionais. $\mathbf{E}$ inadmissivel que um pais com esses dados destine verbas públicas para Escolas confessionais. Se a Igreja quisesse realmente mudar o quadro da educaçào, ela se envolveria na defesa da Escola pública. Defendendo verbas publicas para Escolas confessionais ela deu argumentaçào para o desvio de verbas publicas para empresas educacionais. Esta foi uma derrota que nós nào esperávamos.

Uma outra derrota foi a nào re. gulamentaçāo da carreira para o magistério no ensino privado. A carreira do magistério na Escola pública foi uma conquista. A gestào demoerática representou outra grande conquista para a Escola pública. Mas na escola privada nào, graças a pressōes da
CNBB. A democracia vai bem para a CNBB quando è fora da Igreja, mas dentro da Igreja ela nào defende a democracia.

Estamos fazendo uma critica a esta dicotomia do ensino público e do ensino privado e à posiçào da Igreja, porque esta Constituinte assumiu posiçòes retrógradas. Creio que a derrota maior neste capitulo nào está representado na quantidade, mas na qualidade, na concepçào de educaçāo que expressa. É uma concepçāo ainda burocrática. Ela nảo resgata a divida que a educacào brasileira tem com a classe trabalhadora. Essa divida diz respeito a uma educaçāo solidăria, uma educaçāo que forme pessoas para a solidariedade. Fala-se em formacào da cidadania como um conceito de iluminismo, mas nào se fala do direito da pessoa, do direito do sujeito, do individuo.

Fala-se em participaçào, mas se retira a alma da Escola. Por exemplo, nào se coloca a Escola como centro gerador da própria política educacio. nal, nào se coloca o professor como o iniciador da própria educaçāo. Nào se valorizou o professor, nào se valorizou a sala de aula de forma decisiva nesta Constituiçào e nem no atual ante-projeto de LDB que é pior que a Lei anterior. Esse projeto do deputado Otávio Elisio é pior do que o que Clemente Mariano, em 1947, mandou para a Câmara. Porque foi elaborado ao nivel dessas entidades da pós-graduaçào, mas nào chegou na base. Nào se ouviu a base, mas alguns intelectuais dessas entidades, que apenas, trabalham, que militam ao nivel de pós-graduação. Eu creio que é pior ainda, porque mantém a mesma estrutura de Conselho Federal de Edueaçà, de Conselho Estadual de Educacào. $\dot{E}$ ainda o Presidente da Republica quem nomeia os Conselheiros. Que conquista é essa? Eu entendo que nós devemos questionar profundamente a forma deste projeto.

É preciso questionar essa auto. nomia da burocracia. A burocracia se autonomizou a tal ponto que, se hoje se fechasse o MEC durante um ano, as escolas nāo saberiam. Nào è que nós nào precisamos de burocracia; precisamos de uma burocracia emancipadora como diria Weber, de uma "racionalidade emancipadora". Este projeto de lei năo questiona a forma de escolha dos dirigentes do $\mathrm{MEC}$, que é feita hoje pelo apadrinhamen- to, fisiologismo, favoritismo. Esses sāo os critérios de escolha. É preciso questionar profundamente essa Constituiçào e o seu prolongamento: Lei de Diretrizes e Bases.

Creio que o atual projeto de LDB nāo enfrenta o problema do empobrecimento da Escola; um novo projeto pedagógico que deve inserir-se neste grande "Projeto Para o Brasil" precisa conter dispositivos no sentido da retomada da capacidade da Escola, de resolver os seus problemas, de experimentar pedagogicamente, como propunha Florestan Fernandes. E necessário experimentar, errar, "chutar" , quer dizer, possibilitar à Escola fazer o seu projeto. $\dot{E}$ fundamental que nesse "Programa Aternativo de Governo", conste isso como uma concepçào alternativa. Nosso objetivo é conquistar na LDB aquilo que o Florestan propôs: um Conselho de Desenvolvimento Educacional para gerar planos, o que justamente está faltando. Não faltam leis, faltam planos concretos de in. tervençào. Faltam iniciativas. $\mathrm{E}$ isso poderia ser feito através desse "Plano Nacional de Educaçāo" elaborado através desse Conselho de Desenvol. vimento Educacional, superando-se a concepçào privatizante e autoritária, gerada pelos Conselhos Federal e Estaduais, os quais até hoje foram tomados de assalto pela empresa priva. da.

É preeiso que a $\mathrm{LDB}$ saia da pós-graduaçào e ganhe as ruas e as escolas.

Um segundo ponto: um Plano Alternativo de Governo deve ter um pouco mais de ousadia, do que apenas legitimar as conquistas atingidas até agora. É preciso, também, năo ficar a reboque do Estado. É necessário tomar iniciativa. Tenho defendido uma idéia para superar essa dicotomia en. tre ensino público e ensino privado e essa perversidade que é a de reservar o ensino superior apenas àqueles que se formam (ou, pelo menos, a maior parte daqueles que se formam) nas escolas privadas de elite.

Nāo basta priorizar o ensino fundamental para as classes trabalhadoras e deixar o ensino superior apenas para as elites que se formam na escola privada. Insisto na idéia da criaça de um "Sistema Nacional Unificado de Educaçào". Que os alu. nos das Escolas públicas tenham prioridade na Universidade püblica. Que as Universidades püblicas privi- 
legiem a entrada de quem está na Escola pública, que é a classe trabalhadora.

Eu defendi isso na Comissão de Educacào, Cultura, Esporte e Lazer. Nào houve condiçóes de incluir isso, evidentemente, nesta nova Constituiçāo, pela pressāo das escolas privadas, eujo objetivo é formar a elite para colocar na Universidade. Acho que nós temos que colocar a sério esta questāo. No dia em que a Escola fundamental for estendida para todos, intensificará o conflito entre o ensino público e ensino privado. Defendo a idéia de unificaçào do ensino público. Muitos defendem, simplesmente, a extinçào do ensino privado. Acho que nào se tem de extinǵuir, tem-se de asfixià-lo, o que é diferente. É o Estado que assegura hoje a politica priva. tizante. No projeto da Constituiçāo enviado pelo PT ao Congresso, previa-se a extinçāo em dez anos do ensino privado. Foi uma posiçào tomada pelo Diretório Nacional. A imediata suspensào da concessào do direito à abertura de escolas para o ensino privado e depois, em dez anos, a sua ex. tinçāo. Creio que nāo é por ai. Temos de definir uma tática concreta de articulaçào de todo o sistema de ensino público para valorizá-lo eomo um todo. Por outro lado, engajar a Universidade pública no resgate do ensino público de primeiro e segundo graus, eliminando-se o vestibular para quem segue a Escola pública.

$O$ teste da administraçāo municipal de São Paulo nos oferece outros dados. Um partido que tem uma proposta como o PT, quando chega a uma Prefeitura como a de Sảo Paulo e começa a colocar em açāo suas propostas, em cem dias, de que o Jânio fez em très anos. Nào triplicamos apenas o salário (de dezembro para o mès de abril) para todos os funcionários, mas implantamos Colegiados em vá. rios niveis.

A mudança estrutural que estamos fazendo é uma mudança de espírito do carater burocrático da Secretaria. Queremos fazer com que os órgàos da Secretaria pensem a educaçào. Nós transferimos a merenda escolar para a Secretaria do Abastecimento e a Saúde Escolar para a Secretaria de Higiene e Satide. Ninguém, anteriormente, conseguiu tirar essas duas atividades da Secretaria da Educaçāo, porque havia interesses político-económicos.

Eu sou otimista. Se o PT, junto com uma coligaçāo ampla, ganhar a
Presidència da República, nós temos quadros e concepçào na área de edu. caçāo suficientes para mudar esse Pais. Temos de ser ambiciosos para ultrapassar o que está aí.

Quanto ao earáter do Plano Alternativo de Governo: alguns insistem - isso foi colocado em reuniòes anteriores - que nào vai ser um programa socialista, porque nảo dá para colocar o socialismo como bandeira de luta neste momento. Mas eu acho que náo devemos ter medo do socialismo e mostrar, pedagogjcamente, que avanços em direçāo ao socialismo sảo possiveis hoje. Nào adianta, taticamente, renunciar ao referencial que nós temos que é o socialismo. Porque o povo vai dizer: "eles estảo fazendo a mesma coisa que o Brizola fez", isto é, vão, taticamente, se aliar a esses grupos de empresários. Nào adianta renunciar. Nossa cara é essa mesma, nossa cara é socialista. Agora, nâo precisamos de um socialismo rançoso, daquela coisa que afastaria o voto. Mas nós temos de nos apresentar como socialistas.

Só que neste momento o nosso programa não precisa ser estritamen. te socialista, mas um programa popular e democrático em direçâo ao socialismo. Ele tem de ter a cara do PT que é socialista. Neho que isso dá a tônica do programa, porque nào adiantá só um programa tecnicamen. te perfeito se ele náo tiver uma cara nova que alimente a esperança. Eu acho que toi isso que o PT soube fazer nas últimas eleiçöes. Essa coerència do PT fez com que ele ganhasse as eleiçoes. Nào foi porque fez concessóes em relação ao seu programa. A Erundina, aqui em Sào Paulo, jamais fez concessōes. Temos de nos apresentar com clareza e objetividade. $\mathrm{Na}$ educaçào, sobretudo, acho que nós podemos continuar ousando. Temos de carregar esse programa de uma alternativa na área de alafabetizaçào. Nós temos de dar uma resposta a es. ses 35 milhōes de brasileiros que nāo conseguem, por falta de instrumental que a alfabetizaçào dá, participar de. eisivamente dos destinos desse País. Eu acho, portanto, que temos de insistir nesse programa de alfabetizaçào, temos de insistir na educaçào ambiental, que é uma questâo fundamental. E tambèm na educaçâo extra-formal: a escola nāo é o único espaço onde há educação.

Para terminar, eu queria tocar em dois pontos polêmicos que são a questào de tempo integral e a da mu. nicipalizaçăo. Acho que o Programa também tem de se pronunciar sobre isso. Ilá posiçòes divergentes, inclusive dentro do $\mathrm{PT}$, com relaça à municipalizaçāo. Mas eu aqui queria distinguir duas coisas: uma é a educação municipalque, hoje.já conta com mais de 350 mil professores; e outra é a transferencia das escolas do Estado para o Municipio e isso é o que pode. ria ser questionável, o que se chama de municipalizacào. Por outro lado, o combate à municipalizaça feito por algumas entidades nào deve supor que o Municipio deixe de pensar na educaçào. Seria realmente castrar a capacidade de orǵanizaçāo popular, inclusive, de participaçāo, de poder popular, se disséssemos que a edueaçào tem de ser pensada somente ao nivel Federal e Estadual. Parece-me que este combate à municipalizaçào está virando um grande tigre de papel. E com isso está se perdendo a capacidade de intervençáo nos municipios. A verba que os municipios têm, está sendo desviada para outras atividades porque nảo há nem projetos de educaçào em muitos municipios brasileiros. A verba vai para cultura, para alimentaçāo, etc. Acho que tem de ser levada a sério a questāo da educaçào municipal.

Quanto ao periodo integral, há divergèncias no PT. Um dos argumentos contrários a essa idéia è o seguinte: enquanto nào houver escola para todos, nào se deve lutar pelo tempo integral, há quem considere este um projeto quercista ou brizolista. Na minha visào, o tempo integral é ideal. É una conquista necessaria. A permanència da criança na escola por quatro horas e mais très ou quatro onde for possivel, obviamente, com orientação pedagógica adequada, é uma necessidade social que responde às necessidades dos trabalhadores.

Nossas propostas educacionais no"PlanoAlternativo do Governo"devem conter um programa de resgate de austeridade, de valorização da sala de aula e do professor. Temos de fa. zer isso se quisermos inverter a prio. ridade da política educacional da ditadura. Por que há tanta falta de professores? Nào é só porque ele è mal pago, mas porque nào existe um projeto que garanta sua permanèneia na Escola em tempo integral, para orientaçào de alunos, correçào de avalia. çóes, preparaçāo de aulas. Precisa. mos lutar contra o burocratismo, o legalismo, para deixar a Escola fun. cionar livremente. 